\title{
Growth, chlorophyll $\alpha$ and protein of the marine microalga Isochrysis galbana in batch cultures with different salinities and high nutrient concentrations
}

\author{
Fabregas, J., Herrero, C., Abalde, J., Cabezas, B. \\ Departamento de Microbiologia, Facultades de Farmacia y Medicina, Universidad de \\ Santiago, Santiago de Compostela, Spain
}

Fabregas J, Herrero C, Abalde J, Cabezas B. Growth, chlorophyll a and protein of the marine microalga Isochrysis galbana in batch cultures with different salinities and high nutrient concentrations. Aquaculture 1985;50(1-2):1-11.

ISSN: 00448486

DOI: 10.1016/0044-8486(85)90147-4

\begin{abstract}
Cultures of the marine microalga Isochrysis galbana were grown under 56 different nutrient concentration-salinity conditions, ranging from 1 to $64 \mathrm{mM} \mathrm{NaNO}_{3}$ and from 0 to $35 \%$ salinity. Salinity and nutrient concentration were found to be closely related to I. galbana growth and to the biochemical composition. Optimal growth conditions were between 15 and 35\%o salinity and nutrient concentrations of 2, 4 and $8 \mathrm{mM} \mathrm{NaNO}_{3}$, resulting in one doubling/day and a maximum cellular density of $20 \times 106 \mathrm{cell} / \mathrm{ml}$. Variations in salinity and in nutrient concentration had a greater effect on the final biomass than on the growth velocity. Maximum values of chlorophyll $\alpha \mathrm{ml}$ were found with 2, 4 and $8 \mathrm{mM} \mathrm{NaNO}_{3}$ and between 15 and 35\%。 salinity. Chlorophyll a cell values were more homogeneously distributed between 15 and $35 \%$ salinity and 1 to $8 \mathrm{mM} \mathrm{NaNO}_{3}$, although maximum concentrations (37 pg chlorophyll $\alpha$ cell) were reached at $10-15 \%$ with all the nutrient concentrations. Protein per $\mathrm{ml}$ of culture and protein per cell were closely related to salinity and nutrient concentration. Maximum values of $387 \mu \mathrm{g} / \mathrm{ml}$ and $18.6 \mathrm{pg} /$ cell were obtained at $15-35 \%$ salinity and 4-8 $\mathrm{mM} \mathrm{NaNO}_{3}$.
\end{abstract}


The nitrate-protein transformation rate was related to nutrient concentration. Maximum rate was $84 \%$ at $15 \%$ salinity and $1 \mathrm{mM} \mathrm{NaNO}_{3}$. Nutrient concentrations higher than $16 \mathrm{mM}$ $\mathrm{NaNO}_{3}$ produced a strong decrease in the efficiency at all salinities.

\section{Introduction}

Microorganisms are potentially useful as food for human consumption, in the production of chemicals and in the bioconversion of solar energy (Kharatyan, 1978; Goldman, 1979). The marine microalga Isochrysis galbana (Haptophyceae) is at present widely used in aquaculture (Walne, 1974; Bayne, 1976; Epifanio, 1979). Knowing its growth response in a wide range of nutrient concentrations and salinity conditions in batch culture, we can establish some of the parameters for mass production that enable us to obtain maximum cellular density and better efficiency in the nitrate- $\mathrm{N} /$ protein- $\mathrm{N}$ transformation rate, and ascertain its biochemical variability in response to environmental action.

Several studies have revealed significant differences in the ability of various species or classes of microalgae to utilize nutrients at low concentrations. Such studies have provided much useful information on the adaptabilities of marine microalgae and have significant implications regarding competition between species under various conditions of limiting nutrients (Laws and Bannister, 1980). In contrast, micro algal cultures at high nutrient concentrations are usually made to obtain maximum production of total biomass in aquaculture, or of a given product for particular industrial applications, utilizing as small a culture volume as possible. Optimum conditions for subsequent mass culture of marine microalgae at high nutrient concentrations (Fabregas et al., 1985) can be established, in part or completely, using batch cultures (Fabregas et al., 1984a).

Salinity, nutrient concentration, light, temperature and carbon source can be considered as the most important parameters for culturing marine microalgae. In the present work we analyzed the response of the marine microalga Isochrysis galbana to $7 \times 8$ nutrient concentration-salinity conditions, maintaining constant $\mathrm{pH}$, temperature and carbon source, and light saturation.

\section{Materials and methods}

The marine microalga Isochrysis galbana was obtained from The Culture Centre for Algae and Protozoa, Cambridge, England. It was cultured in seawater filtered through a $0.45 \mathrm{J1}$ Millipore filter, autoclaved at $120^{\circ} \mathrm{C}$ for $60 \mathrm{~min}$ and enriched with $\mathrm{NaNO}_{3}, 2 \mathrm{mM} ; \mathrm{NaH}_{2} \mathrm{PO}_{4}$, $100 \mu M ; \mathrm{ZnCl}_{2}, 1 \mu M ; \mathrm{MnC12}, 1 \mu M ; \mathrm{Na}_{2} \mathrm{MoO}_{4}, 1 \mu M ; \mathrm{CoCl}_{3}, 0.1 \mu M ; \mathrm{CuSO}_{4}, 0.1 \mu M$; ferric 
citrate, $20 \mu \mathrm{M}$; thiamine, $35 \mu \mathrm{g} / \mathrm{l}$; biotin, $5 \mu \mathrm{g} / \mathrm{l}$; B12 , $3 \mu \mathrm{g} / \mathrm{l}$; EDTA, $26.4 \mathrm{mM}$; Tris-HCl, 15 $m M ; \mathrm{pH} 7.6$.

We used eight salinities: $35,30,25,20,15,10,5$ and $0 \%$. The salinityof the seawater $(35 \%$ ) was reduced by the addition of appropriate volumes of fresh distilled water prior to medium preparation. The first nutrient concentration utilized was the one whose composition was the half of that given above and which corresponds to $\mathrm{NaNO}_{3}, 1 \mathrm{mM}$. From this we followed a geometrical progression, using concentrations corresponding to 2, 4, 8, 16, 32 and $64 \mathrm{mM}$ of $\mathrm{NaNO}_{3}$. Nutrient concentrations are expressed as $\mathrm{NaNO}_{3}$ concentrations, but refer to the whole medium.

Cultures were carried out in Kimax screw-capped test tubes $(15 \times 2.5 \mathrm{~cm})$ with $40 \mathrm{ml}$ of medium. All cultures were maintained in a controlled environment incubator (New Brunswick) at $15^{\circ} \mathrm{C}$ and 3900 lux light from fluorescent lamps (Phillips TL 20W/55). A 12:12 light-dark regime was maintained in order to obtain synchronous cultures. An inoculum of $1 \times 10^{5}$ logarithmic phase cells $/ \mathrm{ml}$ was used. The present conditions are based on the light saturation recommended by Kain and Fogg (1958) and temperature optimum of $16 \pm 1^{\circ} \mathrm{C}$ (Ukeles, 1961); pH remained below 8.9 (Fig. 1), since the rate of growth was inhibited in Isochrysis galbana at pH 8.75 and above (Kain and Fogg, 1958).

Transmittance of the cultures was determined by using a Coleman II 6/20 spectrophotometer reading at $530 \mathrm{~nm}$ and values were expressed as (100 - T). Cellular density was determined by counting culture aliquots in a Thoma chamber.

Chlorophylls were extracted from the cells in acetone-methanol $2: 1$ at $4^{\circ} \mathrm{C}$ for $48 \mathrm{~h}$. The extracts were filtered through a Fluoropore Millipore filter for clarification (Fabregas et al., 1984b), and absorbances of the pigment extract at specific wavelengths were recorded. The concentration of chlorophyll $\alpha$ was determined by the formula of Parsons and Strickland (1965).

Protein was measured in the stationary phase by the dye-binding method (Bradford, 1976).

Stationary phases, corresponding to maximum biomass production, were compared by an overall multivariate one-way analysis of variance (ANOV A), and logarithmic phases, that indicate the growth velocity of the cultures, were compared by a one-way analysis of covariance (ANCOVA).

\section{Results and discussion}


We plotted transmittance against time and against salinity for each nutrient concentration, obtaining three-dimensional figures (Fig. 2). Statistical treatment of these figures is presented in Table I.

We can establish the kinetics of the cultures in the logarithmic and in the stationary phases from transmittance $(100$ - T) measurements. In the stationary phases, transmittance measurements can be transformed into cellular densities. It is generally accepted that a relation exists between optical density and cellular density (Lyon and Woo, 1980; Fabregas et al., 1984a). It is more accurate to quantify the biomass of a micro algal culture by transmittance than by cellular densities obtained by counting in a chamber, although the reverse may be true for micro algae with a high associated bacterial flora or in culture conditions that enhance bacterial growth. In our culture conditions, bacterial growth is enhanced at salinities of 0 and $5 \%$ for all nutrient concentrations. At these salinities therefore, a relationship between transmittance and cellular density cannot be established.

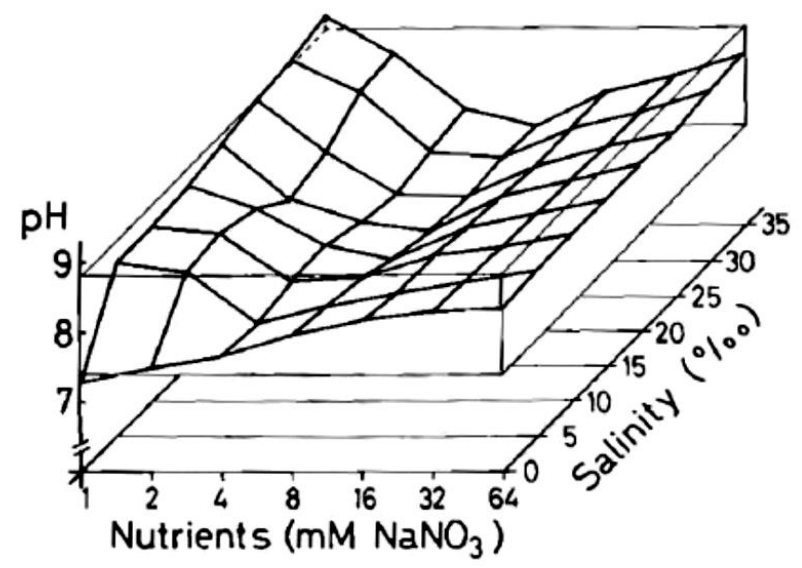

Fig. 1. $\mathrm{pH}$ values in stationary phase cultures of $I$. galbana at different salinities and nu-trient concentrations.

In our experiments, the relation between $(100-\mathrm{T})$ measured at $530 \mathrm{~nm}$ in screw-capped test tubes ( $2.5 \mathrm{~cm}$ light run) and cellular density in the stationary phase was established only for the optimum growth interval and fitted to a linear curve $y=1.90 x+42.74$ where $y=$ transmittance expressed as $(100-\mathrm{T})$ and $x==$ cellular density, with a correlation coefficient of 0.95 . This relation was only calculated for the stationary phase.

There was a strong relationship between salinity-nutrient concentration conditions and the final biomass production in the stationary phase. Optimal growth conditions for obtaining maximum cellular density in the stationary phase were $15-35 \%$ salinity and 2 to $8 \mathrm{mM}$ of $\mathrm{NaNO}_{3}$ (Fig. 3), with cellular densities of $17 \times 10^{6}$ to $20 \times 10^{6}$ cells $/ \mathrm{ml}$ (Table 2). Salinities of 15 to $25 \%$ (Laing and Utting, 1980) and of 15 to $40 \%$ (Kain and Fogg, 1958) were found to be optimal for I. galbana growth. 
With the remaining salinity-nutrient concentration conditions, cellular density decreased significanctly, and an interaction between salinity and nutrient concentration can be observed. At optimal salinities of 15-35\%, the limiting growth factor in the cultures with $1 \mathrm{mM}$ of $\mathrm{NaNO}_{3}$ is probably nutrient depletion in the culture media. At salinities between 0 and $10 \%$ and for all nutrient concentrations, the growth limitation is possibly due to the lack of certain compounds present in the seawater that are indispensable for micro algal growth but that are not included in the culture medium. Growth decrease is proportional to salinity decrease. At high nutrient concentrations another limiting factor is introduced, the toxicity produced by high TRIS concentrations (Kain and Fogg, 1958; Guillard and Ryther,1962), since the culture medium used was buffered with TRIS (Pintner and Provasoli, 1958; Guillard and Ryther, 1962; McLachlan and Gorham, 1962; Sorge and McLaughlin, 1970).

\section{TABLE 1}

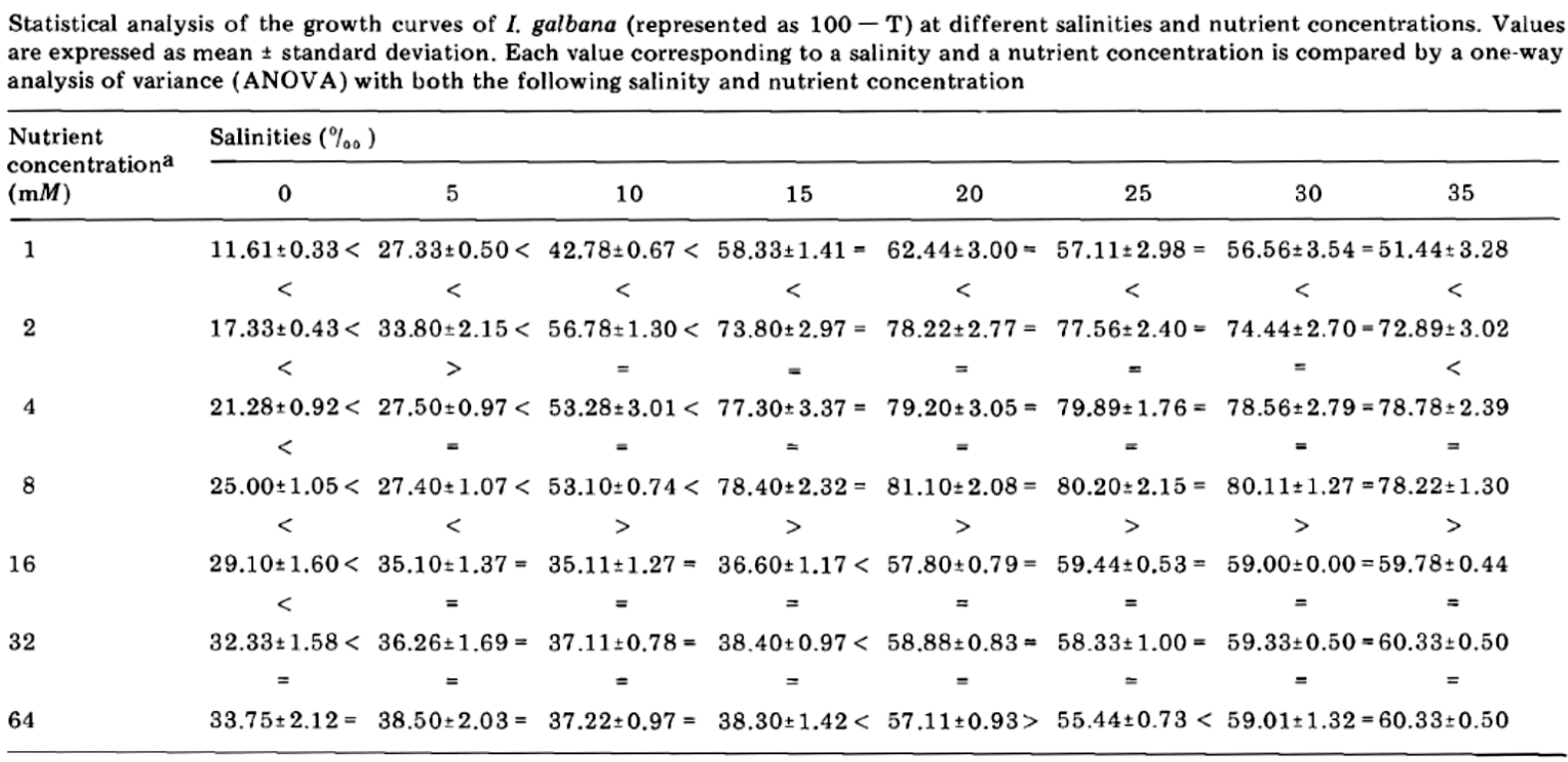

a Expressed as $\mathrm{NaNO}_{3}$ concentration

Salinity and nutrient concentrations have no effect on the growth velocity of $I$. galbana in synchronous cultures. Growth velocity in the logarithmic phase was one doubling/day under all conditions except for $0 \%$ salinity. Values higher than one doubling/day were not obtained because we worked with synchronous cultures due to the light-dark 12: 12 regime maintained. Because of this synchronization, the microalgal population can be considered theoretically as a single cell whose biomass is equivalent to the biomass of the population; in this way, we obtained more homogeneous information about the cellular kinetics.

Maximum values of chlorophyll $\alpha$ ranged between 2.6 and $4.43 \mu \mathrm{g} / \mathrm{ml}$ at $15-35 \%$ salinity and 2-8 $\mathrm{mM}$ of $\mathrm{NaNO}_{3}$ (Table 2). Chlorophyll a quickly decreased with the remaining salinitynutrient concentration conditions. When the salinity increased, the chlorophyll a tended to increase, as it did also in function of the nutrient concentration (Fig. 4). The chlorophyll content in the cultures was closely related to cellular density. 

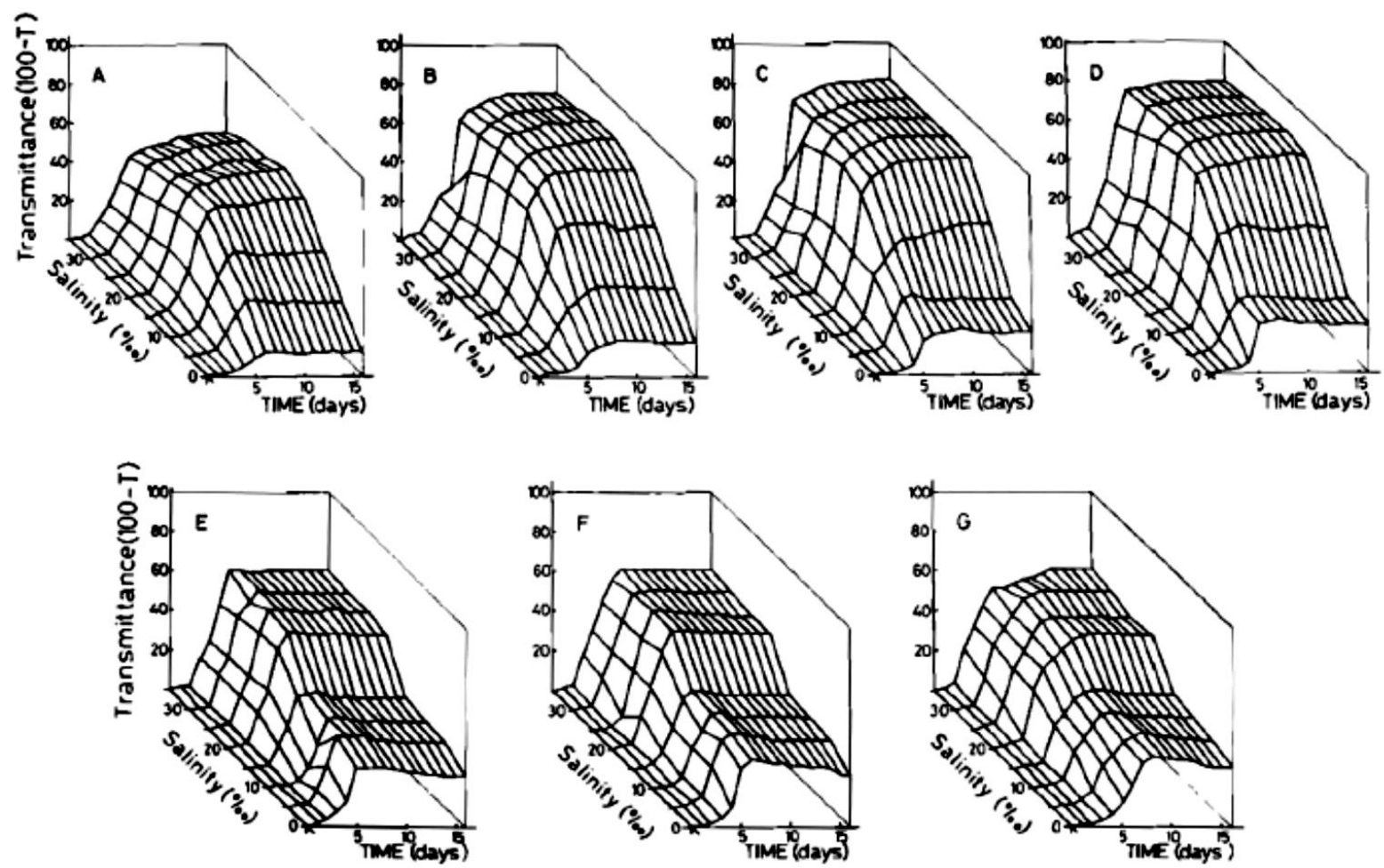

Fig. 2. Growth of I. galbana at different salinities and nutrient concentrations, expressed as $\mathrm{NaNO}_{3}$ concentrations. Transmittance at $530 \mathrm{~nm}$ is represented as $(100-\mathrm{T})$ values. (A) Nutrient concentration $1 \mathrm{mM} \mathrm{NaNO}$; (B) $2 \mathrm{mM}$; (C) $4 \mathrm{mM}$; (D) $8 \mathrm{mM}$; (E) $16 \mathrm{mM}$; (F) $32 \mathrm{mM}$ and (G) $64 \mathrm{mM}$.

Maximum concentrations of chlorophyll $\alpha$ per cell were obtained at 2, 4 and $8 m \mathrm{maNO}_{3}$ (Table 2). Chlorophyll a/cell decreased at higher nutrient concentrations. Maximum concentrations of chlorophyll $\alpha$ /cell were found at 10 and $15 \%$ salinity for any nutrient concentration.

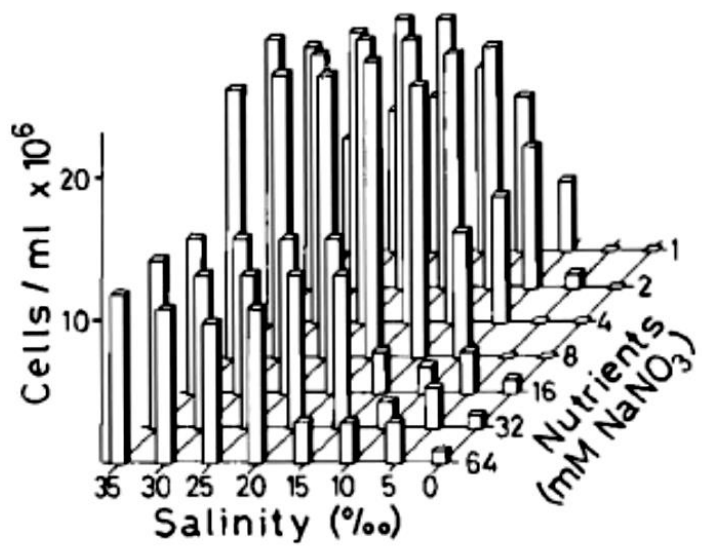

Fig. 3. Maximum cellular densities of I. galbana in the stationary phase at different salinities and nutrient concentrations.

Samples for protein measurement were always collected at the same time because protein concentration varies depending on the moment in the light period at which the sample is taken (Van Liere et al., 1979). Nutrient concentration affected the protein content of $I$. 
galbana cultures (Fig. 5). Maximum protein concentrations per ml were 209 and $387 \mu \mathrm{g} / \mathrm{ml}$, found with 15 and $35 \%$ salinity and 4 to $8 \mathrm{mM}$ of $\mathrm{NaNO}_{3}$. Maximum protein concentrations per cell were found under the same conditions, with values between 10 and $18.4 \mathrm{pg} / \mathrm{cell}$ (Table 2).

\section{TABLE 2}

Values obtained for the stationary phase of $I$. galbana cultures at different salinities $(0-35 \%$ ) and nutrient concentrations $(1-64 \mathrm{mM})$. (A) cells/ml; (B) chlorophyll $a$, $\mu \mathrm{g} / \mathrm{ml}$; (C) chlorophyll $a, \mathrm{pg} /$ cell; (D) protein, $\mu \mathrm{g} / \mathrm{ml}$; (E) protein, $\mathrm{pg} /$ cell; (F) nitrate-N/ protein-N transformation rate (efficiency). Values lower than $2 \times 10^{6} \mathrm{cell} / \mathrm{ml}$ are not considered and are not used for calculating the ratios chlorophyll $a /$ cell and protein/ cell. Chlorophyll $a$ values lower than $0.1 \mu \mathrm{g} / \mathrm{ml}$ and protein values lower than $1.0 \mu \mathrm{g} / \mathrm{ml}$ are also not considered

\begin{tabular}{|c|c|c|c|c|c|c|c|c|}
\hline A & 0 & 5 & 10 & 15 & 20 & 25 & 30 & 35 \\
\hline 1 & - & - & 5 & 11 & 13 & 11 & 10 & 8 \\
\hline 2 & - & - & 10 & 17 & 19 & 19 & 18 & 17 \\
\hline 4 & - & - & 9 & 19 & 20 & 20 & 19 & 20 \\
\hline 8 & - & - & 9 & 19 & 21 & 20 & 20 & 19 \\
\hline 16 & - & 3 & 2 & 3 & 11 & 11 & 11 & 11 \\
\hline 32 & - & 2 & 2 & 3 & 11 & 11 & 11 & 12 \\
\hline 64 & - & 3 & 3 & 3 & 11 & 10 & 11 & 12 \\
\hline \multicolumn{9}{|l|}{ B } \\
\hline & 0 & 5 & 10 & 15 & 20 & 25 & 30 & 35 \\
\hline 1 & - & 1.1 & 1.8 & 2.4 & 2.2 & 2.6 & 2.3 & 1.8 \\
\hline 2 & - & 1.6 & 2.1 & 3.3 & 4.2 & 4.1 & 3.0 & 2.6 \\
\hline 4 & - & 0.8 & 2.1 & 3.6 & 3.9 & 3.6 & 3.6 & 3.0 \\
\hline 8 & - & 0.6 & 1.8 & 3.8 & 4.4 & 4.2 & 4.5 & 3.1 \\
\hline 16 & - & 0.8 & 0.3 & 0.6 & 0.8 & 1.1 & 1.3 & 1.2 \\
\hline 32 & - & 0.6 & 0.3 & 0.5 & 0.3 & 0.6 & 1.0 & 0.8 \\
\hline 64 & - & 0.5 & 0.6 & 0.6 & 0.8 & 0.9 & 1.0 & 1.1 \\
\hline
\end{tabular}




\begin{tabular}{|c|c|c|c|c|c|c|c|c|}
\hline $\mathrm{C}$ & & & & & & & & \\
\hline & 0 & 5 & 10 & 15 & 20 & 25 & 30 & 35 \\
\hline 1 & - & - & 0.37 & 0.22 & 0.17 & 0.24 & 0.23 & 0.23 \\
\hline 2 & - & - & 0.21 & 0.20 & 0.22 & 0.21 & 0.17 & 0.15 \\
\hline 4 & - & - & 0.24 & 0.19 & 0.19 & 0.18 & 0.19 & 0.15 \\
\hline 8 & - & - & 0.21 & 0.20 & 0.21 & 0.21 & 0.23 & 0.16 \\
\hline 16 & - & 0.28 & 0.19 & 0.22 & 0.08 & 0.10 & 0.12 & 0.11 \\
\hline 32 & - & 0.22 & 0.15 & 0.17 & 0.03 & 0.06 & 0.09 & 0.07 \\
\hline 64 & - & 0.29 & 0.20 & 0.20 & 0.07 & 0.09 & 0.09 & 0.09 \\
\hline $\mathrm{D}$ & & & & & & & & \\
\hline & 0 & 5 & 10 & 15 & 20 & 25 & 30 & 35 \\
\hline 1 & - & 23.8 & 49.91 & 74.3 & 72.7 & 40.9 & 44.7 & 51.0 \\
\hline 2 & - & 63.6 & 80.1 & 136.6 & 102.4 & 103 & 99.0 & 132 \\
\hline 4 & - & 25.4 & 99.0 & 219 & 213 & 201.6 & 209 & 237 \\
\hline 8 & - & 15.6 & 30.3 & 194 & 387 & 291.8 & 273 & 228 \\
\hline 16 & - & 2.3 & 1.1 & 4.6 & 7.7 & 8.7 & 13.2 & 18.8 \\
\hline 32 & - & 2.9 & 5.5 & 4.6 & 7.5 & 7.6 & 8.9 & 18.8 \\
\hline 64 & - & 4.1 & 7.4 & 8.8 & 11.8 & 11 & 11.7 & 19.9 \\
\hline$E$ & & & & & & & & \\
\hline & 0 & $\tilde{5}$ & 10 & 15 & 20 & 25 & 30 & 35 \\
\hline 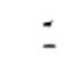 & - & - & 10 & 6.7 & 5.6 & 3.7 & 4.4 & 6.3 \\
\hline 2 & - & - & 8 & 8.0 & 5.4 & 4.4 & 5.5 & 7.7 \\
\hline 4 & - & - & 11 & 11.5 & 10.6 & 10.1 & 11 & 11.8 \\
\hline 8 & - & - & 3.3 & 15.5 & 18.4 & 14.6 & 13.6 & 12.1 \\
\hline 16 & - & 0.7 & 0.6 & 1.5 & 0.7 & 0.8 & 1.2 & 1.7 \\
\hline 32 & - & 0.9 & 2.7 & 1.5 & 0.7 & 0.7 & 0.8 & 1.7 \\
\hline 64 & - & 1.4 & 2.4 & 2.9 & 1.0 & 1.1 & 1.1 & 1.6 \\
\hline $\mathrm{F}$ & & & & & & & & \\
\hline & 0 & $\vdots$ & 10 & 15 & 20 & 25 & 30 & 35 \\
\hline 1 & - & 27 & 57 & 84 & 83 & 47 & 51 & 58 \\
\hline 2 & - & 36 & 45 & 78 & 58 & 59 & 57 & 75 \\
\hline 4 & - & 7.2 & 28 & 62 & 61 & 57 & 60 & 77 \\
\hline 8 & - & 2.2 & 4.3 & 42 & 55 & 41 & 39 & 32 \\
\hline 16 & - & 0.1 & 0.08 & 0.3 & 0.54 & 0.61 & 0.93 & 1.3 \\
\hline 32 & - & 0.1 & 0.19 & 0.16 & 0.26 & 0.27 & 0.31 & 0.66 \\
\hline 64 & - & 0.07 & 0.13 & 0.15 & 0.20 & 0.19 & 0.20 & 0.35 \\
\hline
\end{tabular}

When the nutrient concentration increased, the total protein content of the cultures increased proportionally up to a nutrient concentration of $8 \mathrm{mM} \mathrm{NaNO}_{3}$, but with higher nutrient concentrations the total protein content of the cultures diminished drastically. Protein/cell ratio varied with the nutrient concentration in the same way as protein $/ \mathrm{ml}$. 
Salinity had more effect on the total protein content of the cultures than on the protein per cell, and this effect was more marked at low than at high nutrient concentrations. These results are different from those found for the marine microalga Tetraselmis suecica under the same culture conditions (Fabregas et al., 1984a).
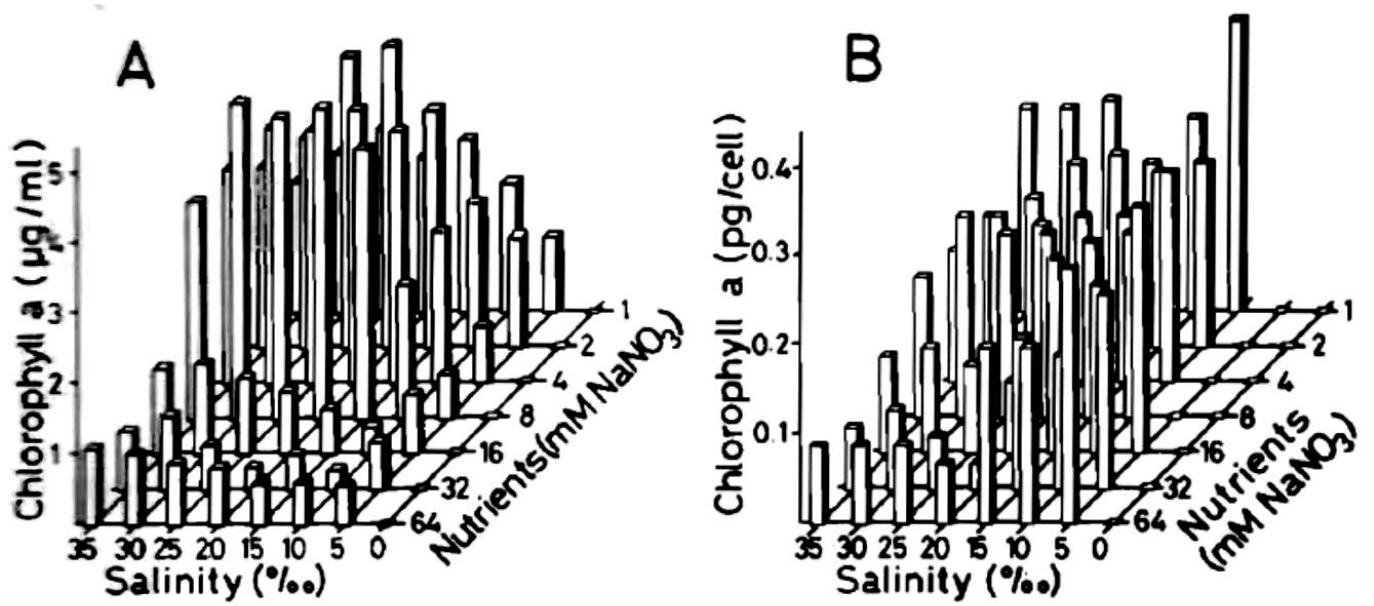

Fig. 4. Chlorophyll $a$ concentration in stationary phase cultures of $I$. galbana at different salinities and nutrient concentrations. (A) Chlorophyll $a$ per $\mathrm{ml}(\mu \mathrm{g} / \mathrm{ml}) ;(B)$ Chlorophyll a per cell (pg/cell).
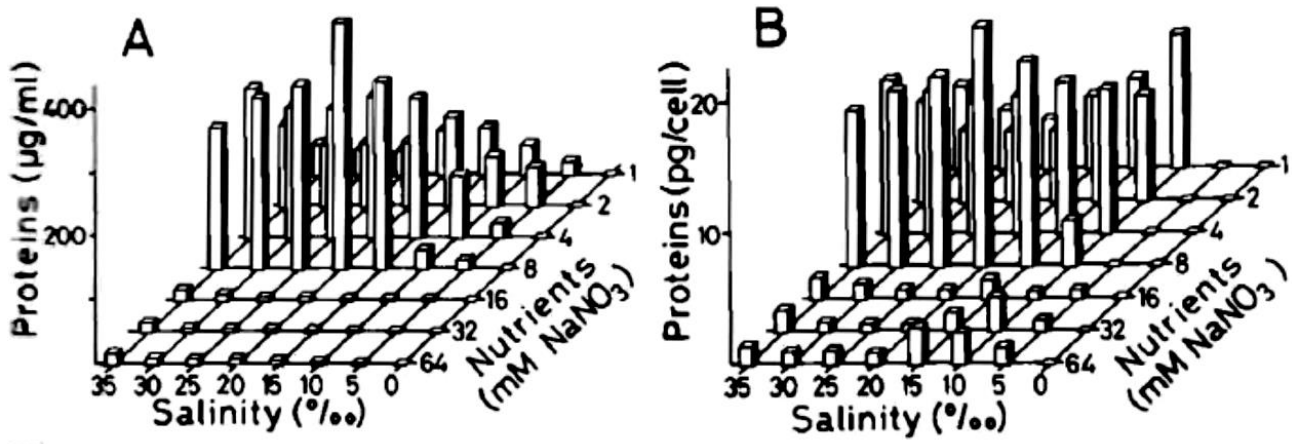

Fig. 5. Protein concentration in stationary phase cultures of $I$. galbana at different salinities and nutrient concentrations. (A) Protein per $\mathrm{ml}(\mu \mathrm{g} / \mathrm{ml})$; (B) Protein per cell (pg/cell).

Changes in the protein content are not necessarily related to cellular density in the cultures because the biochemical composition of I. galbana may change within more or less narrow limits depending on environmental action.

I. galbana showed considerable variability in its protein and chlorophyll $\alpha$ content related to salinity and nutrient concentrations. These data are in general agreement with those of other authors, indicating that the nutrient supply influences the chlorophyll $\alpha$ and protein content of unialgal cultures (Myklestad, 1974; Fabregas et al., 1984a). 


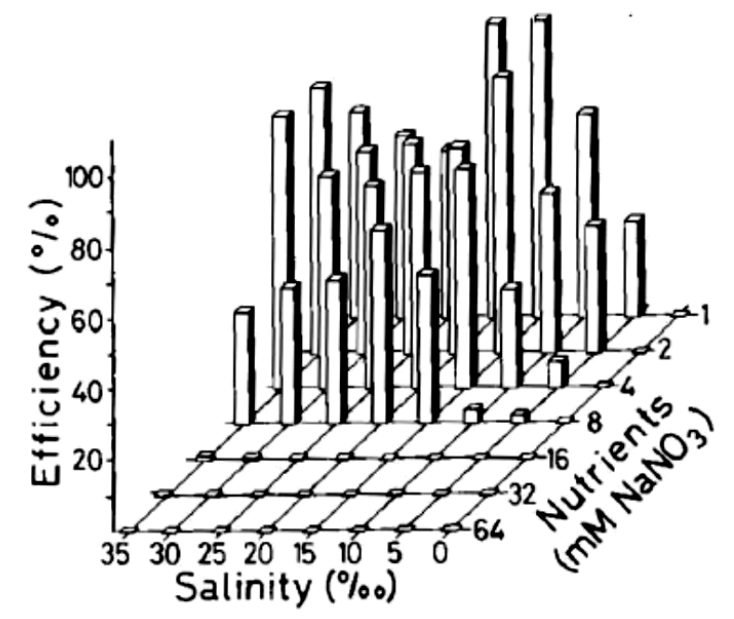

Fig. 6. Nitrate-N/protein-N transformation rate (efficiency) in stationary phase cultures of I. galbana at different salinities and nutrient concentrations.

We established the efficiency of nitrate-N/protein- $\mathrm{N}$ transformation as the ratio between nitrogen added in nitrate form to the culture medium and the protein nitrogen produced per culture. Conversion was most efficient between 10 and 35\%o salinity and between 1 and 8 $\mathrm{mM} \mathrm{NaNO}_{3}$ (Fig. 6), with maximum values of 83 and $84 \%$ obtained at $15-20 \%$ salinity and 1 $\mathrm{mM} \mathrm{NaNO}_{3}$ (Table 2). Similar values, with a maximum of $64 \%$, were obtained for the marine micro alga Tetraselmis suecica in batch culture (Fabregas et al., 1984a). Maximum efficiencies were found with $1 \mathrm{mM} \mathrm{NaNO}_{3}$, at which concentration a maximum transformation of nutrient into micro algal biomass occurred. With higher concentrations the most important growth-limiting factor is the carbon source, since in seawater the inorganic carbon concentration is about $2 \mathrm{mM}$ (Burris, 1977). An increase in the nutrient concentration did not produce an increase in biomass production, but $\mathrm{CO}_{2}$ added to the cultures increased the final biomass production, so that carbon limitation is evident. Due to this carbon limitation the growth conditions were not the most suitable for micro algal cells to utilize all the nitrate available in the culture media and, therefore, efficiencies decreased.

\section{Acknowledgements}

Thanks to Professor Dr. B. Regueiro Varela for his interesting comments, to Professor Dr. C. Ferreiros for excellent help in statistical analysis and to Professor Dr. B. Regueiro Garcia for allowing us access to computational facilities. This work was supported by a grant of the Direccion General de Ordenacion Pesquera, Ministerio de Agricultura, Pesca y Alimentacion, Spain. 


\section{References}

1. Bayne BL. The biology of mussel larvae. Marine Mussels: Their Ecology and Physiology 1976:81-120.

2. Bradford MM. A rapid and sensitive method for the quantitation of microgram quantities of protein utilizing the principle of protein-dye binding. Anal Biochem 1976;72(1-2):248-54.

3. Burris JE. Photosynthesis, photorespiration, and dark respiration in eight species of algae. Mar Biol 1977;39(4):371-9.

4. Epifanio CE. Comparison of yeast and algal diets for bivalve molluscs. Aquaculture 1979;16(3):187-92.

5. Fabregas J, Abalde J, Herrero C, Cabezas B, Veiga M. Growth of the marine microalga tetraselmis suecica in batch cultures with different salinities and nutrient concentrations. Aquaculture 1984;42(3-4):207-15.

6. Fabregas J, Herrero C, Veiga M. Effect of oil and dispersant on growth and chlorophyll a content of the marine microalga tetraselmis suecica. Appl Environ Microbiol 1984;47(2):445-7.

7. Fabregas J, Herrero C, Cabezas B, Abalde J. Mass culture and biochemical variability of the marine microalga tetraselmis suecica kylin (butch) with high nutrient concentrations. Aquaculture 1985;49(3-4):231-44.

8. Goldman JC. Outdoor algal mass cultures. I. applications. Water Res 1979;13(1):1-19.

9. Guillard RR, Ryther JH. Studies of marine planktonic diatoms. I. cyclotella nana hustedt, and detonula confervacea (cleve) gran. Can J Microbiol 1962;8:229-39.

10. Kain J, Fogg G. Studies on the growth of marine phytoplankton II isochrysis galbana. J Mar Biol Assoc U K 1958;37:781-8.

11. Kharatyan SG. Microbes as food for humans. Annu Rev Microbiol 1978;32:301-27.

12. Laing I, Utting $\mathrm{S}$. The influence of salinity on the production of two commercially important unicellular marine algae. Aquaculture 1980;21:79-86.

13. Laws EA, Bannister TT. Nutrient- and light-limited growth of thalassiosira fluviatilis in continuous culture, with implications for phytoplankton growth in the ocean. Limnol Oceanogr 1980;25(3):457-73.

14. Lyon HW, Woo CS. Accelerated uptake response of the green alga, chlorella vulgaris, to high levels of phosphorus in mississippi river water. Science of the Total Environment, the 1980;14(3):279-85.

15. McLachlan J, Gorham PR. Effects of $\mathrm{pH}$ and nitrogen sources on growth of microcystis aeruginosa kütz. Can J Microbiol 1962;8(1):1-11.

16. Myklestad S. Production of carbohydrates by marine planktonic diatoms. I. comparison of nine different species in culture. J Exp Mar Biol Ecol 1974;15(3):261-74.

17. Parsons TR, Strickland JDH. Particulate organic matter. III.I. pigment analysis. III.I.I. determination of phytoplankton pigments. J.Fish.Res.Board can. 1965;18:117-27.

18. Pintner IJ, Provasoli L. Artificial cultivation of a red-pigmented marine blue-green alga, phormidium persicinum. J Gen Microbiol 1958;18(1):190-7. 
19. Sorge E, McLaughlin J. Physiological studies of algae isolated from a polluted biotope. Dev Ind Microbiol 1970;12:109-25.

20. Ukeles $\mathrm{R}$. The effect of temperature on the growth and survival of several marine algal species. Biol Bull 1961;120(2):255-64.

21. Van Liere L, Mur LR, Gibson CE, Herdman M. Growth and physiology of oscillatoria agardhii gomont cultivated in continuous culture with a light-dark cycle. Arch Microbiol 1979;123(3):3158.

22. Walne PR. Culture of Bivalve Molluscs 1974. 